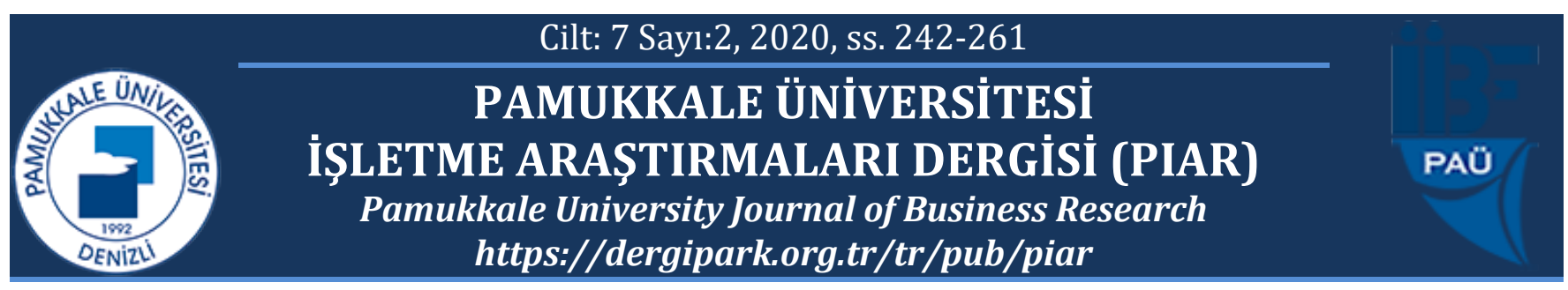

\title{
Pay/Katılma Paylarının Anayasa'nın 73. Maddesi Çerçevesinde Değerlendirilmesi
}

\section{Evaluation of Share / Participation Shares within the Frame of Article 73 of the Constitution}

\section{İbrahim ORGAN ${ }^{1} \quad$ Hamit ÇETİN ${ }^{*}$}

\author{
${ }_{1}^{1}$ Pamukkale Üniversitesi, İ̈BF, iorgan@pau.edu.tr, https://orcid.org/0000-0003-4986-0805 \\ 2 Süleyman Demirel Üniversitesi, İ̈BF, hamitcetin@sdu.edu.tr, https://orcid.org/0000-0001-8629-1045 \\ * Yazışılan Yazar/Corresponding author
}

\section{Öz}

Ülkemizde nüfusun gelişmesine paralel olarak kamu harcamaları da artış göstermiş bu bağlamda kamu harcamaları finansman kaynă̆ına ihtiyaç da her geçen gün artış göstermektedir. Yerel yönetimler, kamu hizmetinde bulunurken katlanmış oldukları giderlere söz konusu hizmetlerden fayda elde edenlerin de katılmasin isterler. Dolayısıla belirli bir katılım payı belirlenmektedir. Anayasa mahkemesi kararlar irdelendiğinde, Harcamalara katılma payını benzeri mali yükümlülük olduğu görülmüş, dolayısıyla bunların Anayasa'nın 73. maddesi çerçevesinde "ödeme gücü" ilkesine uygun olarak tahsil edileceği açıktır. Belirlenen katılım payının sosyal devlet ve hukuk devleti ilkelerine aykırı olmaması önem arz etmektedir. Bu çalışmada katılma paylari; belediyelerin yetkisine bırakılan harcamalara katılma payları, sağlık hizmeti sunumunda katılım payı ve garanti fonuna katılım payları incelenmiştir. Incelenen katılım paylarının Anayasa'nın 73. Maddesi çerçevesinde ayrıntılı olarak değerlendirilmiştir, bu bağlamda bazı önerilerde bulunulmuştur.

Anahtar kelimeler: Katılma Payları, Vergi Değeri, Anayasa, Ödeme Gücü

JEL kodlarn: $\mathrm{HO}, \mathrm{H} 1, \mathrm{H} 2$

\begin{abstract}
In our country, public expenditures also increased in parallel with the development of the population. Local governments want those who benefit from these services to participate in the expenses they incur while serving the public service. Therefore, a certain contribution is determined. When the decisions of the Constitutional Court are examined, it is seen that the contribution to expenditures is a similar financial obligation, therefore it is clear that they will be collected in accordance with the principle of "solvency" within the framework of Article 73 of the Constitution. It is important that the determined contribution fee is not contrary to the principles of social state and rule of law. In this context, the need for public expenditures financing source is increasing day by day. Participation shares in this study; the shares of participation in the expenditures left to the authority of the municipalities, the share of participation in the provision of health services and the shares of the guarantee fund were examined. The participation shares examined were evaluated in detail within the framework of Article 73 of the Constitution, and some suggestions were made in this context.
\end{abstract}

Keywords: Participation Shares, Tax Value, Constitution, Solvency

JEL codes: $\mathrm{HO}, \mathrm{H} 1, \mathrm{H} 2$ 


\section{GİRIŞ̧}

Vergi ödevinde bireyin, tarifi yapılan bir hizmetten doğrudan doğruya faydalanması karşılığı olarak bir ödemede bulunması yerine, kamu hizmet giderlerinin bütününe karşı anonim bir katılma payını üstlenmesi söz konusudur. Harç, resim ve katılma paylarının Türk hukukunda teknik anlamda vergiden farklı olmalarına rağmen vergiler ile birlikte düzenlenmektedirler. Fakat diğer mali yükümlülükler vergilerden farklı yasal düzenlemelere bağlıdırlar.

Vergi, genel anlamda karşılıksız olma özelliğinden dolayı resim, harç ve benzeri mali yükümlülükten ayırt edilmektedir. Vergiyi resim harç ve benzeri mali yükümlülükten ayıran bir diğer özellik ise Anayasa'nın 73/1 maddesinde yer alan mali güce göre alınması ile ilgili husustur. Vergi dişındaki hiçbir mali yükümlülük için mali güç ilkesi aranmamaktadır. Dolayısıyla benzeri mali yükümlülükler ile vergiyi birbirinden ayırt etmekte herhangi bir sıkıntı yaşanmazken söz konusu yükümlülükleri harç ve resimden ayırt etmek ise oldukça zordur.

Anayasa Mahkemesi tarafindan; yol, kanalizasyon ve su hizmetlerinden fayda sağlayanlardan tahsil edilen harcamalara katılma paylar $1^{1}$ benzeri mali yükümlülük olarak kabul edilmişken sağlık hizmetleri katılım payları ise söz konusu yükümlülüğün dışında bırakılmıştır.

$\mathrm{Bu}$ çalışmada belediyelerin gelir kaynaklarından olan ve Anayasa Mahkemesi tarafından benzeri mali yükümlülük olarak kabul edilen harcamalara katılma payları olarak ifade edilen "yol harcamalarına katılma payı, kanalizasyon harcamalarına katılma payı, su tesisi harcamalarına katılma payının" yanı sıra benzeri mali yükümlülüğün dışında bırakılan "sağlık hizmetleri sunumuna katılım payı ile garanti fonuna katılım payları" Anayasa'nın 73. maddesi çerçevesinde değerlendirilmiştir.

\section{KAMU HIZZMETİ UYGULAMASINDAN DOĞAN ALACAKLAR}

Toplumda, ortak ihtiyaçların kişiler arasında işbölümüne dayanan bir yöntem vasıtasıyla giderilmesi durumu ortaya çıktığında devlet söz konusu alana müdahalede bulunarak bu ihtiyacı gidermek amacıyla kullanmış olduğu temel araçlardan birisi kamu hizmetidir. En geniş anlamda kamu hizmeti, devlet ya da kamu tüzel kişilerce veya bunların gözetim ya da denetimleri altında, genel ve ortak ihtiyaçları karşılamak, kamu yarar veya çıkarını sağlamak amacıyla yapılan ve topluma takdim edilen sürekli ve düzenli etkinlikler olarak tanımlanırken, dar anlamda ise kamu idare ve müesseselerinin kamu hukuku usulleri çerçevesinde ve kamu hukukundan meydana gelen yetki ve ayrıcalıklara dayanılarak göstermiş olduğu faaliyet ve hizmetler şeklinde tanımlanabilmektedir (Budak ve Benk, 2011: 65).

6183 sayılı Kanunun 1. Maddesinde "akitten, haksız fiil ve haksız iktisaptan doğanlar dışında kalan" ifadesi dikkate alındığında devletin özel hukuk hükümleri çerçevesinde hareket ettiği faaliyetler dışında kalan bütün gelirlerin Kanun kapsamında oldukları dile getirilmektedir. Kısacası, devletin ve il özel idarelerin ve belediyelerin sunmuş oldukları hizmetlerin kamu

${ }^{1}$ Anayasa Mahkemesi 28.03.2002, E. 2001/5, K. 2002/42 sayılı kararı, Resmi Gazete, 05.09.2002, S. 24867. 
hizmeti karşılığı olarak tahsilatı yapılacak gelirler 6183 sayılı Kanun gereği kamu alacağı olarak kabul edilmektedir (Budak ve Benk, 2011: 66).

6183 sayılı Kanunda kamu alacaklarına yer verilmiştir. Söz konusu kanun kapsamındaki kamu alacakları beş gruba ayrılmış ve bu gruplardan birisi de Kamu Hizmetleri Uygulamasından Doğan Kamu Alacaklarıdır. Kamu hizmetleri uygulamasından doğan kamu alacaklarının alt başlığında ise Katılma Payları yer almaktadır (Gerçek, 2010: 5).

\section{BENZERİ MALİ YÜKÜMLER}

Benzeri mali yükümlülük kavramı, Anayasa Mahkemesi'nin incelenmiş olduğu kavramlardan biridir. Benzeri mali yükümlülüklerin tam anlamda bir tanımı bulunmamaktadır. Anayasa'da vergi, resim, harç ve benzeri mali yükümlülükler ifadesine yer verilmiştir. Benzeri mali yükümlülük kavramının mahiyetinin belirlenebilmesi için bu kavrama benzeyen kavramların da ele alınıp incelenmesi önem arz etmektedir (Yılmaz ve Biyan, 2016: 336).

Vergi, kamu yönetimi tarafından kamu giderlerini finanse etmek amacıyla, hizmetlerin belirli bir karşıllı̆ı olmaksızın kanun esasları çerçevesinde gerçek ve tüzel kişilerden zorunlu bir şekilde tahsil edilen değerler olarak tanımlanmaktadır (Herekman, 1989: 5). Devletin bireylere hemen seçilebilir bir karşılık sunmaksızın devlet egemenliğine ve yaptırım gücüne dayanarak vergi adı altında alınan değerler olarak da ifade edilebilmesi mümkündür (Uluatam, 2014: 297). Diğer bir ifade ile vergi; devletin kamu giderlerini finanse etmek amacıyla toplumu oluşturan kişi ve kurumlardan, ödeme güçleri nispetinde karşıllısıı ve cebri olarak tahsil edilen nakdi değerlerdir ( Pehlivan, 2014: 87). Vergilerin karşılığ verginin tahsil edilen mükelleflerce devletten, münhasıran kendilerine yönelik olarak bir mal veya hizmet talebinde bulunmaları söz konusu değildir. Devletin, vergi gelirleri ile finanse ederek üretmiş olduğu mal ve hizmetlerden, herkes ödemiş olduğu vergi miktarı nispetinde değil , eşit ölçüde faydalanma hakkına sahiptir (Pehlivan, 2014: 88). Dolayısıyla vergiler belli bir hizmetin karşılığı değil tüm kamu hizmetlerinin karşılığı olarak ifade edilebilirler (Herekman, 1989: 5). Harçlar, devlet veya başka bir kamu kurum ya da kuruluşu tarafından sunulmuş olan ve bir ticari ya da sınai nitelik taşımayıp kamusal nitelik taşıyan hizmetlerin karşıllğı olarak söz konusu hizmetlerden fayda elde edenlerden tahsil edilen nakdi bedellerdir (Şen ve Sağbaş, 2015: 34). Diğer bir ifade ile harçlar, özel menfaatlerine bağlı olarak bireylerin, kamu kurum ve kuruluşlarından elde etmiş oldukları fayda karşılığ1 ödemiş oldukları değer şeklinde tanımlanmaktadır (Akdoğan, 2009: 104). Vergilerin aksine, bir harcın ödenmesi hemen hemen daima kamusal bir özel karşılık ile ilişki hali söz konusu olup, seviyeleri genellikle masrafların karşılanması ilkesine göre belirlenir (Turhan, 1982: 3031). Diğer bir ifade ile harçları, yarı kamusal nitelik taşıyan kamu mal ve hizmetleri sunan kamu kuruluşlarınca sunulan hizmetlerden fayda sağlayanların elde etmiş oldukları fayda derecelerine göre zorunlu bir şekilde tahsil edilen nakdi bedeller şeklinde tanımlamak da mümkündür ( Şen ve Sağbaş, 2015: 34). Harca konu olan hizmet ile harç arasında bir karşılık ilişkisi olması itibari ile vergiden ayrılmaktadır. Harç, toplum yararına yönelik olarak yapılan har hangi bir hizmetten özel yarar elde edilmesinin karşılığı olarak alınır. Harçlar da vergi gibi cebri olarak alınırlar yani isteğe bağlı olarak ödenmeleri söz konusu değildir. Pasaport harcı, öğrenim harcı buna örnek gösterilebilir. Harçlar da vergiler gibi kanun ya da kanunun vermiş olduğu yetkiye dayanılarak uygulamaya konur (Altay, 2015: 123-124; Muter 
vd., 2008: 105). Resim ise, kamu giderlerinin karşılanması için, belirli bir hizmetin veya işin faaliyete geçirilmesi amacıyla yetkili makamlar tarafından verilmiş olan iznin karşılığı olarak tahsil edilen para şeklinde tanımlanmaktadır. Resim bazen harca, bazen de vergiye benzeyen bir kamu geliri türüdür (Yılmaz ve Biyan, 2016: 338; Muter vd., 2008: 105). Daha çok yerel yönetim kuruluşlarınca tahsil olunan resimlere, merkezi yönetim gelirleri arasında görmek de mümkündür (Akdoğan, 2009: 106).

Vergi, genel anlamda karşılıksız olma özelliğinden dolayı resim, harç ve benzeri mali yükümlülükten ayırt edilmektedir. Vergiyi resim harç ve benzeri mali yükümlülükten ayıran bir diğer özellik ise Anayasa'nın 73/1 maddesinde yer alan "mali güce göre alınması" ifadesi ile ilgili husustur. Vergi dışındaki hiçbir mali yükümlülük için mali güç ilkesi aranmamaktadır. Dolayısıyla benzeri mali yükümlülükler ile vergileri birbirinden ayırt etmek kolaydır. Fakat benzeri mali yükümlülüklerin harç ve resimden ayırt edilmesi oldukça zordur. Bu doğrultuda ise Anayasa Mahkemesinin bu konu ile ilgili kararları incelenmelidir (Yılmaz ve Biyan, 2016: 341).

Katılma payları anayasanın 73. Maddesinde yer verilen vergi ve benzeri mali yükümlülük olarak tanımlanabilir mi? Sorusunun cevabı, 5510 sayılı Kanun üzerinden değerlendirilen Anayasa Mahkemesi'nin mali yükümlülük ile ilgili kararında2; "Ücret, aidat, kesenek, harç, katılma payı, fon payı, katkı payı gibi adları ne olursa olsun parasal yükümlülük ya da ödemelerin Anayasa'nın 73. maddesi kapsamında mali yükümlülük sayılabilmesi için ödemenin kamu gideri niteliğinde ve kamu hizmeti karşılı̆̆g olması, tek taraflı irade ile alınması, kamu gücüne dayanması, zorunlu olması, ödenmemesi ha- linde hukuki yolla tahsili, devlet tüzel kişiliği, kamu tüzel kişiliği ya da kamu kurumu niteli- ğinde meslek kuruluşlar tarafindan tahsil edilmesi ve yasa ile konulması gerekir." kriterlerine yer verilmiştir.

Anayasa Mahkemesi tarafindan; yol, kanalizasyon ve su hizmetlerinden fayda sağlayanlardan tahsil edilen harcamalara katılma paylar ${ }^{3}$ benzeri mali yükümlülük olarak kabul edilmiş, sağlık hizmetleri katılım payları ise söz konusu yükümlülügün dışında bırakılmıştır (Eraslan ve Üstün, 2018: 171-172).

\section{KATILMA PAYLARI}

Vergi ödevinde bireyin, tarifi yapılan bir hizmetten doğrudan doğruya faydalanması karşılığı olarak bir ödemede bulunması yerine, kamu hizmet giderlerinin bütününe karşı anonim bir katılma payını üstlenmesi söz konusudur. Harç, resim ve katılma paylarının Türk hukukunda teknik anlamda vergiden farklı olmalarına rağmen vergiler ile birlikte düzenlenmektedirler. Fakat diğer mali yükümlülükler vergilerden farklı yasal düzenlemelere bağlıdırlar (Güneş, 2008: 22).

Belediyeler tarafından tahsil edilen yol, kanalizasyon ve su tesisleri harcamalarına katılma payları (Danıştay, E.2005/1656; Danıştay, E.2001/665), kamu hizmetleri dolayısıyla ortaya çıkan alacaklar arasında kabul edilmektedir (Budak ve Benk, 2011: 66). Kamu hizmetinin uygulamasından dolayı doğan alacaklar 6183 sayılı Kanun kapsamında kamu alacakları olarak kabul edilmektedirler. Belediyelerin tahsil etmiş olduğu yol, kanalizasyon ve su

215.12.2006 tarih ve 2006/11 esas 2006/112 karar sayılı Anayasa Mahkemesi kararı, 30.12.2006 tarih ve 26932 sayılı 5. Mükerrer Resmi Gazete.

${ }^{3}$ Anayasa Mahkemesi 28.03.2002, E. 2001/5, K. 2002/42 sayılı kararı, Resmi Gazete, 05.09.2002, S. 24867. 
tesisleri harcamalarına katılma payları söz konusu kamu alacakları olarak kabul edilmektedirler (Budak ve Benk, 2011: 72).

\section{BELEDIYYELERINN MALİ KAYNAKLARI}

Belediyelerin genel olarak yaşadıkları en temel sorunların başında gelir problemleri gelmektedir. Belediyelerin yıllar itibari ile bütçe gelir-gider dengesi incelendiğinde mahalli idareler bütçesinin 2015 yılında yaklaşık iki milyar TL, 2016 yılında yaklaşık on üç milyar TL, 2017 yılında yaklaşık on sekiz milyar TL, 2018 yılında yaklaşık yirmi altı milyar TL ve 2019 yılında ise yaklaşık olarak on iki milyar TL açık verdiği görülmektedir ${ }^{4}$. Bu durum dikkate alındığında ise belediyelerin ciddi gelir problemleri yaşadıkları söylenebilir. Dolayısıyla belediyelerin özellikle gelir kaynaklarının iyileştirilmesi anlamında yapılan reform ve düzenlemelerde ayrıca üzerinde durulmuştur. Zaman içinde görev ve sorumlulukları artan belediyelerde gelirleri için aynı şey söylenememektedir. Özellikle 1980'li yıllardan sonra mali kaynaklarının artırılması amacıyla yapılmış ciddi çalışmalar olmasına rağmen hedeflenen seviyelere ulaşılamamıştır (Tortop vd., 2014: 344).

Belediyelerin gelir kaynakları yapılan düzenlemeler çerçevesinde öz gelir kaynakları, idareler arası transfer gelirleri ve borçlanma şeklinde üç grup altında incelenebilir. Öz gelir kaynakları, kanunlarla belirlenen sınırlar içerisinde kalmak koşulu ile kontrol yetkisinin belediyelere verildiği gelirlerdir. Belediyelere verilen bu yetkiler öz gelirin türüne ya da bulunduğu devletin idari, siyasi ve ekonomik yapısına bağlı olarak değişim gösterebilmektedir (Arıkboğa, 2016: 278).

Bu bağlamda katılma payları; belediyelerin sahip olduğu sınırları ve mücavir alanlarında yol yapımı, yolların genişletilmesi ve yolların baştan onarılması veya düzenlenmesi, kanalizasyon tesisi faaliyete geçirilmesi ve hali hazırdaki tesislerin aksayan yanlarının düzeltilmesi ile içme suyu tesisinin yeni yapılarak faaliyete geçirilmesi ve mevcut su şebekelerinden işlem görmeyenlerin onarılması karşılığı olarak yapılan bu faaliyetlerden fayda elde eden gayrimenkul sahiplerinden almış oldukları paylardır (Acar ve Aydın, 2015: 191).

Türkiye'de kentsel rantların doğmasında, hem merkezi yönetimin hem de belediyelerin bulundukları faaliyetler etkili olmaktadır. Fakat bunlar tarafından gerçekleştirilen büyük ölçekli kamu yatırımları, planlı şehirleşme ve kentsel dönüşüm gibi faaliyetler dolayısıyla ortaya çıan rantın vergilendirilmesi konusunda başarının sağlandığı söylenemez. Ülkemizde kentsel rantların vergilendirilmesi ile ilgili olarak farklı vergi türleri uygulamaya konulmuştur. Bu vergiler daha çok kıymet artışı (Gayrimenkul kıymet artışı) ve değer artışlarını (Değer Artış Kazançları) vergilendirilmesini konu edinmektedir. Günümüz dünyasında bazı maliye bilim insanları, 2464 sayılı Kanunda düzenlenen Harcamalara Katılma Payları bir rant vergisi olarak değerlendirmektedir. Fakat Harcamalara Katılma Payları, Taşınmaz mallarda meydana gelen değer artışlarını vergilendirmekten ziyade öngörülen harcamaların finansman ihtiyacını belli oranda karşılama amacı gütmesi dolayısıyla vergiden ayrılmaktadır ( Aktaran Yazıcı, D.Ali, 2018: 136).

${ }^{4}$ T.C. Hazine ve Maliye Bakanlığı, Muhasebat Genel Müdürlüğü, https://muhasebat.hmb.gov.tr/mahalli-idarelerbutce-istatistikleri, (Erişim: 30.11.2020). 
Tahsilatı Belediyeler tarafından yapılan harcamalara katılma payı, aynı vergi ve harçlar gibi 2464 sayılı Belediye Gelirleri Kanunu (BGK) çerçevesinde düzenlenmektedir (Toprak, 2017: 185). Harcamalara Katılma Payları, 2464 sayılı Kanunda; yol, su ve kanalizasyon harcamaları şeklinde üç gruba ayrılmıştır. Yol, su ve kanalizasyon harcamaları gayrimenkul değerini artırabilen bir yapıya sahip olması dolayısıyla, katılma payı mükellefliğini harcamanın yapılmış olduğu bölgede bulunan gayrimenkul sahipliği ile ilişkilendirilmiştir. Bu yolla, belediyelerce yapılmış olan kentsel altyapı yatırımlarının belli orandaki payının, söz konusu harcamalar dolayısıyla belli oranda fayda elde etmiş olan kişiler tarafından varlık değerleri ile orantılı bir şekilde karşılanması temeline dayanmaktadır. Kısacası, harcamalara katılma payları, altyapı hizmetlerine finansman sağlayan ile birlikte yapılan harcama sonucu doğan değerin (rant) belli oranının bir nevi vergilendirme vasıtasıyla belediyenin bütçesine tekrardan aktarılması şeklinde ifade edilebilir (Kurtuluş, 2006: 55-56).

Harcamalara katılma payları Belediye Gelirleri Kanununun 3. Maddesinde düzenlenmiştir. Hizmetler büyükşehir belediyesi tarafından yapılması koşuluyla 2464 sayılı Belediye Gelirleri Kanununda yer alan oran ve esaslar nispetinde tahsil edilecek Yol Harcamalarına Katılma Payı, Kanalizasyon Harcamalarına Katılma Payı ve Su Tesisleri Harcamalarına Katılma Payı olmak üzere üç başlık altında toplanmıştır (Toprak, 2017: 185).

Belediyeler tarafından tahsil edilen yol, kanalizasyon ve su tesisleri harcamalarına katılma payları (Danıştay, E.2005/1656; E.2001/665), kamu hizmetleri dolayısıyla doğan kamu alacakları arasında sayılmaktadır (Budak ve Benk, 2011: 66). Bu bağlamda herhangi bir alacağın kamu alacağı olarak (6183 sayılı Kanun kapsamında) değerlemeye alınabilmesi için Devlete, il özel idarelerine ya da belediyelere ait olması mecburidir. Klasik kamu gelirleri olan vergi, resim ve harç gelirleri ile birlikte gümrük ile tekel idareleri tarafından tahsil edilen vergiler, cezalar, parafiskal gelirler, idari özel hukuk sözleşmeleri dolayısıyla ortaya çıan alacaklar ve fon gelirleri de kamu alacağının kapsamına dahil edilebilir. Bunların yanı sıra kamu hizmetinin uygulamaya konulmasından doğan alacaklar da yasa kapsamında kamu alacağı olarak kabul edilmektedir. Belediyeler tarafından tahsil edilen yol, kanalizasyon ve su tesisleri harcamalarına katılma payları kamu hizmetinin uygulamasından kaynaklanan alacaklarda yer almaktadır (Budak ve Benk, 2011: 72).

\subsection{Yol Harcamalarına Katılma Payı}

Harcamalara katılım payı yasal bir düzenleme olarak uzun yıllardır mevcut olmasına rağmen farklı sebeplerden dolayı uygulanmamış ya da uygulaması eksik kalmış yerel kamu geliri olarak kalmıştır. Şehirlerde artış gösteren nüfusun ihtiyacını karşılamak amacıyla belediyeleri söz konusu yerel gelire dikkat çekmeye yöneltmiştir (Arslan, 2014: 128).

Yol harcamalarına katılma payı Belediye Gelirleri Kanunu'nun 86. maddesinde düzenlenmiştir. Söz konusu madde ile, "Belediyelerce veya belediyelere bağlı müesseselerce aşă̆ıdaki şekillerde inşa, tamir ve genişletilmeye tabi tutulan yollarm iki tarafinda bulunan veya başka bir yola çıkışı olmaması dolayısıyla bu yoldan yararlanan gayrimenkullerin sahiplerinden meclis kararı ile Yol Harcamalarına Katılma Payı alınabilir." hükmüne yer verilmiştir.

Bu şekiller yine 86. madde itibariyle;

“a) Yeni yol açılmasi;

b) Mevcut yolların yüzde 40 nispetinde veya daha fazla genişletilmesi; 
c) Kaldırımsız ve bakımsiz bulunan yolların, kaldırım veya parke kaldırım haline getirilmesi veya asfalt yapılması, kaldırım veya şose halindeki yolların da parke, beton veya asfalta çevrilmesi;

d) Mevcut kaldırım veya parkelerin sökülüp yeniden düzenlenmesi ${ }^{5}$, hallerinde bu yolların iki tarafinda bulunan veya başka bir yola çıkışı olmaması dolayısıyla bu yoldan yararlanan gayrimenkullerin sahiplerinden Yol Harcamalarına Katılma Payı alınır." şeklinde hükme bağlanmiştır.

6360 sayılı On dört İlde Büyükşehir Belediyesi ve Yirmi Yedi İlçe Kurulması İle Bazı Kanun Hükmünde Kararnamelerde Değişiklik Yapılmasına Dair Kanun ile değişmeden önceki halde; 2464 sayılı Belediye Gelirleri Kanunu'nun 86/1 maddesine göre belediyeler tarafından yapılmış olan yol harcamalarının karşılığı olarak kanunda belirlenmiş oran ve usuller nispetinde bireylerden Yol Harcamalarına Katılma Payı almaları zorunlu bir durumdu (Arslan, 2014: 129). Temel nedeni ise kanunda "alınır" ifadesinin yer almasıydı. Fakat 6360 sayılı Kanun, Resmi Gazetede 06.12.2012 tarihinde yayımlanarak yürürlüğe girmiş ve "alınır" ifadesi "alınabilir" şeklinde değiştirilmiştir (İpek ve Engin: 471).Yasal düzenlemenin lafzı itibari ile "alınabilir" ifadesi belediyelere söz konusu gelirleri dilerse isteme hakkını ortaya çıkarmıştır (Arslan, 2014: 129).

\subsection{Kanalizasyon Harcamalarına Katılma Payı}

Kanalizasyon harcamalarına katılma payı, Belediye Gelirleri Kanunu'nun 87. maddesinde düzenlenmiştir. Söz konusu maddede; “Belediyelerce ve belediyelere bağlı müesseselerce, aşağıdaki şekilde kanalizasyon tesisi yapılması halinde, bunlardan faydalanan gayrimenkullerin sahiplerinden, Kanalizasyon Harcamalarma Katılma Payı alını:

a) Yeni kanalizasyon tesisi yapılması,

b) Mevcut tesislerin sıhhi ve fenni şartlara göre ıslah edilmesi.

İki ve daha fazla yol kenarmda bulunan gayrimenkuller, hangi yoldaki kanalizasyona bağlanmış ise, payın hesabında o yola ait kanalizasyon giderleri nazara alınır." hükümleri karara bağlanmıştır.

Belediye Gelirleri Kanunu'na göre kanalizasyon harcamalarına katılma payı belediyelerce imar edilen veya iyileştirilmiş olan kanalizasyon tesislerinden fayda sağlayan gayrimenkul sahiplerinden tahsil edilen maddi bir karşılıktır (Arıkboğa, 2019: 38). Söz konusu maddede katılma payının mükellefi olarak yalnızca gayrimenkül sahiplerinin gösterilmesine rağmen gayrimenkul üzerinde intifa hakkının bulunmasının ortaya çıkması halinde katılma payı mükellefinin intifa hakkı sahiplerinin olacağı açıktır. Kanalizasyon harcamalarına katılma payının tahsil edilebilmesi için, gayrimenkulün, tesisin yapılması ya da imar edilen kanalizasyondan fayda sağlıyor veya ileriki zamanlarda fayda elde edilecek olması gereklilik arz etmektedir (Torun, 2017: 459). Dolayısiyla burada harcamalara katılma payı ile fayda elde etme düzeyi arasında kurulan ilişki, adalet ilkesi açısından önem arz etmektedir (Ulusoy ve Akdemir, 2017: 299). Gayrimenkullerin iki veya daha fazla yol kenarında bulunması durumunda, söz konusu yollardan hangisinin kanalizasyonuna bağlantısı

${ }^{5}$ Yolların kaldırımlar da dahil olmak üzere (15) metreden fazla genişliklerine düşen giderler, belediyelere ait olup, harç hesaplanmasında bu giderler nazara alınmaz (BGK, md 86). 
yapılmışsa, payın hesaplanmasında bağlanmış olduğu yola ait kanalizasyon giderleri dikkate alınmaktadır (İpek ve Engin, 2016: 471).

\subsection{Su Tesisleri Harcamalarına Katılma Payı}

$\mathrm{Su}$ tesisleri harcamalarına katılma payı, Belediye Gelirleri Kanunu'nun 88. maddesinde düzenlenmiştir. Söz konusu maddede; "Belediyelerce veya belediyelere bağlı müesseselerce beldede aşă̆ıdaki şekillerde su tesisleri yapılması halinde, dağıtımın yapıldı̆̆ı saha dahilindeki gayrimenkullerin sahiplerinden, Su Tesisleri Harcamalarına Katılma Payı alını:

a) Yeni içme suyu şebeke tesisleri yapılması,

b) Mevcut şebeke tesislerinin tevsii ve ıslahı.

Birden fazla yol kenarında bulunan gayrimenkullere ait payın hesabında, bunlarm yalnız suya bağlandıkları yol üzerindeki uzunlukları esas alını." ifadelerine yer verilmiştir.

Su harcamalarına katılma payı, belediyelerce imar edilen veya iyileştirilmiş olan içme suyu şebeke tesislerinden fayda sağlayan gayrimenkul sahiplerinden tahsil edilen maddi bir karşılıktır (Arıkboğa, :36). Kanunda yer alan su tesislerine yapılan harcamalar, harcama miktarının toplamını aşmamak koşulu ile ilgili gayrimenkul sahiplerine, emlak vergi değerleri nispetinde pay edilmektedir. ${ }^{6}$ (Arıkboğa, 2019: 36).

Söz konusu tesis harcamalarına katılma payı tahsil edilebilmesi için içme suyu şebekelerinin yeni tesis edilmesi ya da önceden tesis edilen şebekelerin genişletilmesi veya imar edilmesi gerekmektedir. Gayrimenkullerin iki veya daha fazla yol kenarında bulunması durumunda, söz konusu yollardan hangisinin su şebekesine bağlantısı yapılmışsa, payın hesaplanmasında suya bağlanmış olduğu yol üzerindeki mesafeleri dikkate alınmaktadır (İpek ve Engin, 2016: 471-472).

Su şebekeleri ile ilgili giderler, gayrimenkul sahiplerine ve kullanıcılarına, belediyeler tarafında yüklenebilecek giderlerden biridir. Suyun kaynağının ortaya çıktığı muhitten, kullanılması amacıyla yerleşkeye getirilmesi hakkında isale hattı giderlerinin yanı sıra ana depo ile dağıtım depolarına bağlı giderlerin katılma payı hesabına dahil edilmemesi gerekmektedir. Madde metninde yer verilen "şebeke tesisi" kavramı, suyu, ana ve dağıtım depolarından hizmetten fayda sağlayanlara ulaştıran boru hatlarına işaret etmektedir (Torun, 2017: 459-460).

Harcamalara katılma payları dikkate alındığında, katılım payları sıfatı ile tahsil edilen bedellerin belediyelerce yol, su, kanalizasyon tesislerine ilişkin olarak sunulan hizmetlerin maliyetine fayda-hizmet ilişkisinden fayda sağlayanların katılımının sağlanması amacı ön planda tutulduğu söylenebilir (Arıkboğa, 2019: 36).

\subsection{Payların Hesaplanması ve Tahsili}

Payların hesaplanması 2464 sayılı Belediye Gelirleri Kanunu'nun 89. maddesinde düzenlenmiştir. Söz konusu kanunda; "Harcamalara katılma payları, bir program dahilinde veya istek üzerine doğrudan doğruya yapılan işlerde, bu hizmetler dolayısıyla yapılan giderlerin tamamıdır. Şu kadar ki yapılacak giderler peşin ödendiği takdirde bu paylar ilgililerden yüzde yirmibeş noksanı ile

${ }^{6}$ Harcamalara Katılma Payı oranı ile ilgili Kanunda bir üst sınır getirilmiştir. Belediye Gelirleri Kanunu'na göre bu oran emlak vergi değerinin \%2'sini geçemez. 
alınır. Ancak, bu tür hizmet giderleri Bayındırlık ve İskan Bakanlı̆̆ı ile İller Bankası tarafından tespit edilen ve yayınlanan rayiç ve birim fiyatlara göre hesaplanan tutarları aşamaz." ibaresine yer verilmiştir. Yine aynı maddede, bina ve arsalarda harcamalara katılma payının \% 2'yi geçemeyeceği hükmüne yer verilmiştir. 89/b. bendinde ise; "Belediyelerin (3030 sayıl kanunun uygulandiğl şehirlerde hizmeti veren belediyelerin) görüşü alınmak suretiyle, Harcamalara Katılma paylarım 1/2'ye (peşin ödemede 1/3'e) kadar indirmeye, pay çeşitlerine göre farklılaştırma yapmaya, payları ödenecek miktarın birlikte veya pay çeşitlerine göre ayrı ayrı olmak üzere Çevre ve Şehircilik Bakanlığınca bildirilecek son genel nüfus sayımı sonuçların da dikkate almak suretiyle ve belediyeler itibariyle tespit etmeye Cumhurbaşkanı yetkilidir." ifadelerine yer verilmiştir.

Harcamalara katılma paylarının tahsil şekilleri de 2464 sayılı Belediye Gelirleri Kanunu'nun 93. maddesinde düzenlenmektedir. Kanun'un 93. maddesinde; "Harcamalara katılma payları belediyelerce veya bunlara bağlı müesseselerce, 92 nci maddeye göre payların ilan ve teblĭ̆ edildiği yılı takip eden yıldan itibaren iki yılda ve dört eşit taksitte, peşin ödemelerle tahakkuk tarihinden itibaren bir ay içinde tahsil olunur. Ancak, yukarıda yazll ödeme sürelerini, ilgili belediyelerin teklifi üzerine, 5 yıla (peşin ödemelerde bir yıla) kadar uzatmaya ve buna göre taksit sürelerini tespit etmeye Cumhurbaşkanı yetkilidir. Cumhurbaşkanınca bu yetkinin kullanılması halinde, uzatılan ödeme süreleri için belediyeler, belediye meclislerinin kararı üzerine ve 6183 sayıl Amme Alacaklarının Tahsil Usulü Hakkında Kanun hükümleri uyarınca alınan tecil faizi oranın aşmamak üzere faiz alabilirler.

Satış, hibe ve trampa gibi devir hallerinde ferağ sırasında o tarihe kadar ödenmemiş taksitler peşin olarak tahsil olunur.

Harcamalara katılma payına tabi gayrimenkullerin listesi belediyelerce ilgili tapu dairelerine bildirilir. Bu gayrimenkullerin satış, hibe ve trampaları halinde tapu dairesi payın tahsilini sağlamak üzere, belediyeyi haberdar eder ve pay ödenmedikçe intikal işlemi yapılmaz."7 ifadelerine yer verilmiştir.

\subsection{Harcamalara Katılma Payının Anayasanın 73. Maddesi Çerçevesinde Değerlendirilmesi}

\subsubsection{Mali Güce Göre Ödeme}

Mali güce göre vergileme ilkesi, bireylerin ekonomik ve kişisel durumlarını dikkate alan bir vergilemenin yapılması anlamı taşımaktadır. Dolayısıyla mali güce göre vergilendirme, vergi yükünün adaletli ve dengeli dağılımı ile sosyal devlet anlayışı ilkelerine ters düşmediği kabul edilmektedir. Bunun yanı sıra farklı gelir grupları arasındaki eşitliği artırarak vergi adaletinin artmasına katkı sağlamaktadır (Şentürk, 2018: 15). Bireyin hem kendisinin ve hem de ailesinin yaşamını devam ettirmeye yetecek gelirin üzerindeki kısmını ifade eden bu ilke, vergi uygulaması açısından önemli olduğu kadar, ulaşılması zor bir özelliğe sahip olduğu bilinmektedir. Verginin ödeme gücüne göre alınması, vergi yükünün dağılımının adil ve mükellefleri zor durumda bırakmayacak şekilde yapılmasını öngörmektedir (Akdoğan, 2009: 216).

${ }^{7} 2464$ sayılı Belediye Gelirleri Kanunu, 29.5.1981 sayılı Resmi Gazete, Sayı: 17354. 


\subsubsection{Anayasa'nın 73. Maddesine göre Harcamalara Katılma Payı}

Anayasa'nın 73. maddesinde, "Herkes, kamu giderlerini karşılamak üzere, mali gücüne göre, vergi ödemekle yükümlüdür. Vergi yükünün adaletli ve dengeli dağılımı, maliye politikasının sosyal amacıdır" ifadesine yer verilmiştir.

27771 sayılı ve 30.11.2010 tarihli Resmi Gazete'de; “Verginin mali güce göre alınması ve genelliği ilkeleriyle vergilendirmede eşitlik ve adaletin gerçekleştirilmesi amaçlanmıştır. Ekonomi ve vergi hukuku alanında mali güce ilişkin göstergelerin gelir, sermaye ve harcamalar olduğu kabul edilmektedir. Mali güç, ödeme gücünün kaynağı, dayanağı, nedeni ve varlık koşuludur. Yasa koyucunun vergilendirmede, kişilerin sahip olduğu ekonomik değer ile mali güçlerini göz önünde bulundurması gerekir.

Mali güce göre vergilendirme, verginin, yükümlülerin ekonomik ve kişisel durumlarna göre alınmasıdır. Bu ilke, aynı zamanda vergide eşitlik ilkesinin uygulama aracı olup, mali gücü fazla olanın mali gücü az olana göre daha fazla vergi ödemesini gerektirir. Vergide eşitlik ilkesi ise mali gücü ayn olanlardan aynı, farklı olanlardan ise farklı oranda vergi alınması esasına dayanır. Diğer bir anlatımla, yükümlülerin genel vergi yüküne kendi ödeme güçlerine göre katılmaların ifade eder." 8 ifadelerine yer verilmiştir.

26923 sayılı ve 01.07.2008 tarihli Resmi Gazete'de; "Verginin mali güce göre alınması ve genelliği ilkeleriyle vergilendirmede eşitlik ve adaletin gerçekleştirilmesi amaçlanmıştır. Ekonomi ve vergi hukuku alanında mali güce ilişkin göstergelerin gelir, sermaye ve harcamalar olduğu kabul edilmektedir. Mali gü̧̈, ödeme gücünün kaynağı, dayanağı, nedeni ve varlık koşuludur. Yasa koyucunun vergilendirmede, kişilerin sahip olduğu ekonomik değer ile mali güçlerini göz önünde bulundurması gerekir.

Herkes tarafından yerine getirilmesi gereken bir yükümlülük olarak kabul edilen ve Devletin kamusal gereksinimlerini karşılaması için egemenlik gücüne dayanarak tek taraflı iradesiyle kişilere yüklediği bir kamu alacă̆ı şeklinde tanımlanan verginin, anayasal sınırlar içinde salınıp toplanması zorunluluğu açıktır. Vergi hukukunda, vergi olgusunun niteliklerini oluşturan yasal düzenlemelerde Anayasanın bu konudaki ilkelerinin özenle göz önünde tutulması gerekir. Bu anlamda, Devletin vergilendirme yetkisi vergide yasallı, mali güç ve genellik gibi kimi anayasal ilkelerle sinırlandırılmıştır. Buna göre vergi, Anayasanın öngördüğ̈̈ ilkeleri gözetecek şekilde kanunla düzenlenmeli ve doğal olarak vergide eşitlik ilkesinin uygulama aracı olan mali gücü de yansıtmalıdır." 9 ifadelerine yer verilmiştir.

"Benzeri mali yükümlülük” ibaresi; Anayasa'nın 73. maddesinin 3. ve 4. fikrasında yer verilmemiştir. Dolayısıyla 1. ve 2. fikraların vergi benzeri mali yükümlülüklerden ziyade sadece vergiler için geçerli olacağı ileri sürülmesi söz konusu madde lafzı itibarıyla hukuken muteberdir (Yiğit, 2018: 444).

Öğretide, Anayasa'nın 73. Maddesinde gerçekleştirilen düzenleme gereği, mali güce göre ödeme ve vergi yükünün adaletli ve dengeli dağılımı ilkelerinin söz konusu maddenin 3. ve 4. fıkralarında düzenlenen vergi benzeri mali yükümlülükler açısından geçerlilik arz etmediği, vergilerden farklı bir şekilde resim, harç ve benzeri mali yükümlülük bakımından

\footnotetext{
${ }^{8}$ Anayasa Mahkemesi Kararı, E.2008/116, K.2010/85, 30.11.2010 tarihli Resmi Gazete, Say1: 27771.

${ }^{9}$ Anayasa Mahkemesinin 20.03.2008 tarih ve E.2004/94, K.2008/83 sayılı kararında (R.G.T. 01.07.2008, Sa.26923)
} 
karşılıklılık ve yararlanma ilkelerinin mevcut olması dolayısıyla söz konusu yükümler için mali güç ilkesinin aranmayacağ ${ }_{1}$ hakkında yaygın bir görüş mevcuttur (Öztürk, 2016: 411).

Anayasa'nın 73. madde gerekçesinde; “Vergi ve benzeri mali yükümlülüklerin adaletli ve dengeli dağılımı ilkesi getirilmiş" ifadesi doğrultusunda benzeri mali yükümlülükleri düzenleyen fikralarda yer almayan "adaletli ve dengeli dağılım" ilkesinin vergiler ile birlikte vergi benzeri mali yükümlülükler için de aranması gerektiği sonucuna ulaşılabilmektedir. Fakat Anayasa Mahkemesi'nin farklı kararları neticesinde vergi benzeri mali yükümlülükleri, vergi yükünün adaletli ve dengeli dağılım ilkesine uygunluğu bakımından denetime tabi tutulmuştur (Yiğit, 2018: 447). Yapılan bu açıklamalar sonucunda harcamalara katılma paylarının Anayasa'nın 73. maddesinde yer alan "mali güce göre ödeme" ilkesi kapsamında irdelenebileceği ile ilgili bir şüphe bulunmamaktadır (Yiğit, 2018: 447).

Anayasa "mali güç" tanımını yapmamış ve mali güç ölçüsü kesin çizgilerle belirtilmemiştir. Fakat kamu maliyesi, gelir, servet ve harcamalarını mali gücün ana göstergeleri olarak ele almaktadır (Şentürk, 2018: 14). Harcamalara katılma paylarında mali güce göre ödeme ilkelerinin kıstaslarından "servet" unsuru esas alınmıştır (Yiğit, 2018: 448).

Bir gerçek ya da tüzel kişinin belli bir dönemde sahip olduğu tüm iktisadi değerlerinin "para ile ifade olunan" toplamına servet denilmektedir (Turhan, 1982: 264; Pehlivan, 2014: 126). Servetin kapsamına her türlü menkul ve gayrimenkul malların yanı sıra sahip olunan nakit para, ziynet eşyası ve alacaklar da girmektedir (Şen ve Sağbaş, 2015: 199).

Yukarda ifade edildiği üzere servet kapsamına sadece gayrimenkuller değil belli bir zaman diliminde sahip olunan tüm iktisadi değerler girmektedir. Harcamalara katılma payı matrahının belirlenmesinde ise servet unsurlarından yalnızca gayrimenkuller dikkate alınmaktadır. Olumsuz kabul edilen bir diğer yön ise, bütün gayrimenkullerin değil yalnızca katılma paylarına konu olacak hizmetle ilişkisi bulunan vergilendirilmeye esas alınmasıdır. Dolayısıyla tüm serveti kavranamadığı, mali gücü gerçekte yansıtmadığı, vergi adaletinin tam anlamıyla sağlanamadığı söylenebilir. Önemli olan bir diğer faktör ise rayiç bedel ile emlak vergi değeri arasında uygulamada mevcut ciddi farklılıklardır. Bu fark, ödeme gücü ilkesi kapsamında harcamalara katılma payının emlak vergi değeri dikkate alınarak yapılan hesaplamanın sağlıklı olmadığını, gerçek anlamda ödeme gücünü yansıtmadığını ortaya koymaktadır. Harcamalara katılma payının temel özellikleri dikkate alındığında sözkonusu harcamalardan yararlanılma oranı veya harcamalara katılma payına konu olan maliyetlerde meydana gelen artış oranı örneğin su tesisleri harcama payında kullanılan boruların birim maliyetindeki artış oranı emlak vergisi değerindeki artış ile her zaman orantılı olamamaktadır (Yiğit, 2018: 448).

Harcamalara katılma payı hesabında bir başka vergi matrahının temel alınması anayasal vergilemenin sosyal nitelikteki ilkeleri olan adalet ve eşitlik ilkesi ile idari nitelikteki vergileme ilkelerinden uygunluk ve belirlilik ilkeleri açısından sorunları bünyesinde sorunlar barındırmaktadır. Servetin tamamını kapsamaması, sadece sunulan hizmet ile ilişkili olan gayrimenkulü kapsaması dolayısıyla vergi adaleti ve eşitlik ilkelerinin ihlal edildiği söylenebilir. Hizmetin ne zaman kullanıma açılacağı, ne kadara mal olacağı ile ilgili olarak mükellefler yeterli bilgiye sahip olamamaktadırlar. Bu sebepten dolayı yıllık gelir durumuna göre harcamalarını planlayan harcamalara katılma payı mükelleflerin mali durumunu olumsuz yönde etkileyebilir. Bu durum ise vergilemenin uygunluk ve belirlilik 
ilkesinin ihlali söz konusudur. Harcamalara katılma payı ile ilgili Kanun hükümleri incelendiğinde;

-Yol harcamalarına katılma payında "yararlanma" gayrimenkullerin sahiplerinden,

-Su tesisleri harcamalarına katılma payında "saha dahilindeki" gayrimenkullerin sahiplerinden

-Kanalizasyon harcamalarına katılma payında "faydalanan" gayrimenkullerin sahiplerinden

Katılma payı alınacağının hükme bağlandığı görülmektedir.

Yararlanma ve faydalanma terimlerinin kullanılması dolayısıyla kanun koyucu mali gücü belirleyen faktörlerden olan servetten ziyade gelir ve harcamayı göstermektedir. Gayrimenkul sahiplerinin tamamının aynı miktar ve ölçüde yararlanmasının imkan dahilinde olmadığı gibi kiralanması durumunda kiracının gayrimenkul sahibine nazaran daha az veya daha fazla miktarda faydalanması durumu ortaya çıkabilmektedir. Bu sebepten dolayı faydalanma veya yararlanma miktarını ölçmeden gayrimenkul sahiplerinden aynı miktarda katılım payı alınması durumunda mali gücün ölçülmemesi anlamı taşımaktadır. Bundan dolayı matrah tespit edilirken yararlanma ve faydalanma miktarını tespit edecek yöntemlere ihtiyaç bulunmaktadır. Dolayısıyla yasada değişikliğe gidilerek gayrimenkulleri sahipleri dışında kiracı gibi kullanıcıları kapsayan bir yöntemin uygulanması uygun olabilmektedir (Yiğit, 2018: 448-449).

Yukarda dile getirilen eksikliklere rağmen bir vergi benzeri mali yükümlülük olan harcamalara katılma payının gayrimenkulün değeri (rayiç ya da vergi değeri) dişında mali güç ilkesi dikkate alınarak ve bu ilkenin gelir, harcama ve servet kriterlerinden birine dayanılarak alınması Anayasa'nın özüne uygun ve anlamlı bir yaklaşımdır. Fakat, katılma payının mükellefi olan kesimlerin sayı olarak çokluğu ve ödeme gücü dolayısıyla toplumun farklı kesimlerini kapsadığı gerçeği dikkate alındığında milyonlarca kişiyi ilgilendiren bir yükümün ödeme ilkesi göz ardı edilerek alınmasının Anayasa'nın sosyal hukuk devleti ilkesi, eşitlik ilkesi, 73. maddesinde yer verilen ödeme gücü ilkesi ve devletin ödevlerini düzenleyen 5. maddesi hükmüyle çelişeceği bilinen bir gerçektir (Yiğit, 2018: 449).

\subsection{Garanti Fonuna Katılma Payı}

Garanti fonunun temel amac1, Garanti Fonu Yönetmeliği'nin 1. maddesinde; “2918 sayılı Karayolları Trafik Kanunu'na göre zorunlu malî sorumluluk sigortasına tabi motorlu araçların sebep olacakları zararların karşılanması amacıyla oluşturulan Garanti Fonu'nun işleyişine, fondan yapılacak ödemelere ve diğer hususlara ilişkin esaslar düzenlemektir." şeklinde ifade edilmiştir. Zarara sebebiyet veren motorlu taşıtın bilinmemesi ya da geçerli bir zorunlu mali sorumluluk sigortaya sahip olunmaması ya da sigortacının iflası veya çalınmış olan motorlu taşıtın işleteninin sorumlu tutulamaması gibi durumlarda birinci fıkrada yer verilen giderler KTK. madde $108^{\prime}$ de $^{10}$ düzenlenen "Karayolu Trafik Garanti Sigortası" tarafından karşılanır (Antalya, 2019: 503).

${ }^{10}$ Ayrıntılı bilgi için bakınız, T.C. Resmi Gazete, 18.10.1983, Sayı: 18195. 
2918 sayılı Karayolları Trafik Kanunu çerçevesinde zorunlu malî sorumluluk sigortasına tabi motorlu araçların neden olacakları zararların karşılanması için oluşturulan Garanti Fonu'nun işleyişine, fondan yapılacak ödemelere ve diğer hususlara ilişkin esasları düzenlemektir.

Zorunlu Malî Sorumluluk Sigortası: 2918 sayılı Kanunu'nda; “Bir motorlu aracın işletilmesinin bir kimsenin ölümü veya yaralanmasina veya bir şeyin zarara uğramasina sebep olması halinde motorlu aracı işletenin sorumluluğunu karşılamak üzere Karayolları Trafik Kanununa göre yapılması zorunlu sigortayı," şeklinde tanımlanmaktadır. Zorunlu mali sorumluluk sigortası, kaza sigortası alanında çalışmaya yetki verilen sigorta şirketleri tarafından yapılır. Söz konusu sigorta şirketlerine zorunlu mali sorumluluk sigortasını yapma yükümlülüğü verilmiştir. Dolayısıyla zorunlu mali sorumluluk sigortası yapılması yasal bir zorunluluk olarak getirilmiş ve ve bu zorunluluk gereği olarak sigorta ettiren ile sigortacı arasında sigorta sözleşmesi yapılmak koşulu ile yasal zorunluluğun yerine getirilmesi sağlanmıştır (Kayıhan ve Ünlükaya, 2018: 127). Motorlu araçların yol açtıkları kazalarda yaralanmış olan bireylerin başta ilk yardım olmak üzere muayenesi ve kontrolü ya da söz konusu yaralanma dolayısıyla ayakta, klinikte, hastane ve diğer yerlerde katlandığı tedavi masrafları ve tedavinin getirmiş olduğu diğer masrafların, aracın zorunlu mali sorumluluk sigortasını yapan sigortacının başvurması tarihinden itibaren 8 iş günü içinde ve zorunlu mali sorumluluk sigortası sinırları kapsamı doğrultusunda ödemede bulunur (Antalya, 2019: 503). Motorlu araç kazaları dolayısıyla meydana gelen maddi zararların tazmin edilmesine ilişkin talepler, zarar gören tarafın, zararı ve tazminat yükümlüsünün öğrendiği tarihten itibaren başlar ve ikinci yılın sonunda kısa süreli bir şekilde zamanaşımına uğrar. Uzun süreli zaman aşımı süresi ise kaza tarihinden başlayarak on yıldır. Manevi zararın tazmin edilmesine ilişkin olarak da kısa süre iki yıl, uzun süre ise on yıldır (Erdoğan, 2019: 165).

Garanti Fonu Yönetmeliğinin, 9. maddesinde Fon gelirleri;

“a) Her yıl, sigorta şirketlerinin 2918 sayılı Karayolları Trafik Kanunu hükümleri uyarınca zorunlu malî sorumluluk sigortası için tahsil ettikleri safi primlerin \% 1'i nisbetindeki katılma paylarl,

b) Zorunlu mali sorumluluk sigortasi yaptıranlarm safi primin \% 2'si orantnda sigorta şirketine ayrıca ödeyecekleri katılma payları

c) Katılma payların zamanında veya tam olarak fon hesabina yatırmayan sigorta şirketlerinden alınacak gecikme zamları.

d) Fon mevduatı için alınan faiz gelirleri,

e) Zaman aşımına uğrayan tazminat karşılıkları,

f) Diğer çeşitli gelirler." şeklinde sıralanmıştır (26.06.1985 tarihli ve 18793 sayılı Resmi Gazete).

Vergi ödevinde bireyin, tarifi yapılan bir hizmetten doğrudan doğruya faydalanması karşıllğı olarak bir ödemede bulunması yerine, kamu hizmet giderlerinin bütününe karşı anonim bir katılma payını üstlenmesi söz konusudur. Altyapı tesislerinden doğrudan faydalanmanın karşılığı olarak tahsil edilen para söz konusu niteliği taşımadığından vergi ve benzeri yükümlülük olarak kabul görmez. Karayollarından, köprülerden tahsil edilen geçiş parası, su, elektrik, havagazı, demiryolları, havayolları, kimi hastane ücretleri gibi, iktisadi 
kıstaslar neticesinde tahsis edilen ve hizmetin konusu tesislerin bakım ve idamesini ve yeni yatırımlar yapılmasını sağlamak amacıyla belirlenen bir fiyattır ve belirtilen nitelikleri bakımından muayyen kamu hizmetleri karşılığı kişilerden tahsil edilen resim, harç veya benzeri mali yükümlülük olarak görülemez. Dolayısıyla, bunların «Gelir Ortaklığı Senedi» vasıtasıyla özel bireylere bırakılmasında Anayasa'nın 73 maddesine aykırı bir taraf söz konusu olmamaktadır (26.06.1985 tarihli ve 18793 sayılı Resmi Gazete) ${ }^{11}$.

\subsection{Sağlık Hizmeti Sunumunda Katılım Payı}

5510 sayılı Kanunu'nun 3/26 bendi dikkate alındığında katılım payı; "Sağllk hizmetlerinden yararlanabilmek için, genel sağlık sigortalısı veya bakmakla yükümlü olduğu kişiler tarafindan ödenecek tutarı" şeklinde tanımlanmıştır. Söz konusu tanım doğrultusunda sağlık hizmeti sunumundan faydalanmak için Sosyal Güvenlik Kurumu (SGK) gibi kamu idaresine ödenmesi mecburi olan bir meblağdır. Yukarıda ifade edilen payın sağlık hizmetlerin sunumundan yararlanmanın bir koşulu olduğu söz konusu Kanunun üçüncü bölümünde yer alan "sağlık hizmetlerinden yararlanma şartları ve katılım payı" başlığından anlaşılması pek de zor olmamaktadir.

5510 sayılı Kanunun 68. maddesinde sağlık hizmetlerinden katılım payı alınacak olanlar sıralanmıştır. Bunlar;

“a) Ayakta tedavide hekim ve diş hekimi muayenesi.

b) (Değişik: 25/6/2009-5917/40 md.) Vücut dışı protez ve ortezler

c) Ayakta tedavide sağlanan ilaçlar. d) (Ek: 25/6/2009-5917/40 md.) Kurumca belirlenecek hastalık gruplarına göre yatarak tedavide finansmanı sağlanan sağlık hizmetleri." şeklinde siralanmıştır.

“(Değişik ikinci fikra: 17/1/2012-6270/9 md.) Katılım payı, birinci fikranın (a) bendindeki sağlık hizmetleri için 2 Türk Lirası olarak uygulanır. Katılım payı, (b) ve (c) bentlerindeki sağlık hizmetleri için gereksiz kullanımı azaltma, sağlık hizmetlerinin niteliği itibarıyla hayati öneme sahip olup olmaması, kişilerin prime esas kazançlarının, gelir ve ayliklarının tutarı ve benzeri ölçütler dikkate alınarak \% 10 ilâ \% 20 oranları arasında olmak üzere Kurumca belirlenir. (Ek cümle: 1/3/2012-6283/2 md.) Yukarıdaki (b) ve (c) bentleri kapsamına giren sağlık hizmetlerinden alınacak katılım payın \% 1'e kadar indirmeye, Kurumun teklifi üzerine Çalışma ve Sosyal Güvenlik Bakanı yetkilidir. Ayrıca Kurum, birinci fikranın (c) bendinde belirtilen sağlık hizmetlerinde, aile hekimlerince yazılan reçeteler dâhil olmak üzere reçetede yer alan üç kalemelüç kutuya kadar ilaç/ilaçlar için 3 Türk Lirası, ilave her bir kalem/kutu ilaç için 1 Türk Lirası olmak üzere katılım payı uygulamaya yetkilidir. Katılım payına ilişkin kutu hesabında enjektable formlar, serum ve beslenme ürünleri ile Kurum tarafindan belirlenecek ilaçlar dikkate alınmaz. Kurum, birinci fikranın (a) bendi gereğgi belirlediği katılım payını; birinci basamak sağlık hizmeti sunucularında yapılan muayenelerde almamaya ya da daha düşük tutarlarda belirlemeye veya tekrar birinci fikranın (a) bendi için belirlenen tutara getirmeye, ikinci ve üçüncü basamak sağlık hizmet sunucularında yapılan muayenelerde ise müracaat edilen sağlık hizmeti sunucusunun yer aldığı basamak, sağlık hizmeti sunucusunun resmi ve özel sağllk hizmeti sunucusu niteliğinde olup olmaması, önceki basamaklardan sevkli olarak başvurulup başvurulmadığı gibi hususları göz önünde bulundurarak on katına kadar

11T.C. Resmi Gazete, 26.06.1985, Sayı: 18793, https://www.resmigazete.gov.tr/arsiv/18793.pdf, (20.04.2020). 
artırmaya ve sağlık hizmeti sunucuları için farklı belirlemeye yetkilidir. Birinci fikranın (d) bendinde belirtilen sağllk hizmetleri bedelinin \% 1'ine kadar katılım payı alınabilir. \% 1'ine kadar tespit edilen katılım payın almamaya, yarısına kadar indirmeye Kurum yetkilidir. Kurum, bu fikrada belirtilen 1 Türk Lirası, 2 Türk Lirası ve 3 Türk Lirasını, 4/1/1961 tarihli ve 213 sayılı Vergi Usul Kanunu uyarınca belirlenen yeniden değerleme oranına kadar her yıl artırmaya yetkilidir." ifadelerine yer verilmiştir.

Türk Anayasası'nın 56. maddesi gereği ülkemizde sağlık hizmetlerinin tek bir elden yürütülmesi zorunlu kılınmıştır. Ülkenin söz konusu hizmetleri yoğun bir şekilde sunmak amacıyla kanun ile genel sağlık sigortası kurması da öngörülmüşsür (Batırel, 2020: 1016).

Kanun gereği; "Genel sağllk sigortasından sağlanacak sağllk hizmetlerinden ve diğer haklardan yararlanmak, genel sağlık sigortahısı ve bakmakla yükümlü olduğu kişiler için bir hak, Kurum için ise bu hizmet ve hakların finansmanın sağlamak bir yükümحlülüktür. Sağllk hizmetlerinden ve diğer haklardan genel sağlık sigortalısı ile bakmakla yükümlü olduğu kişiler yararlandırılır. Bu Kanun kapsamındaki kişilere sağlanacak sağlık hizmetleri ve diğer haklar ile kişilerden alınan primlerin tutarı arasında ilişki kurulamaz." hükmü karara bağlanmıştır. Fakat bu madde hizmetten faydalanan bireyin ödemede bulunmaması durumu düzenlenmediğinden katılım payını ödeyemeyenlerin sağlık hakkından faydalanamayacağı şeklinde bir sonuç ortaya çıkmaktadır (Batırel, 2020: 1016).

Kanunda; "Ayakta tedavi edilen sağlık hizmetleri için katılım payı 2 TL olarak uygulanır. Katılım payı, (b) ve (c) bentlerindeki sağlık hizmetleri için gereksiz kullanımı azaltma, sağlık hizmetlerinin niteliği itibarıyla hayati öneme sahip olup olmaması, kişilerin prime esas kazançlarının, gelir ve aylıklarının tutarı ve benzeri ölçütler dikkate alınarak \% 10 ilâ \% 20 oranları arasında olmak üzere Kurumca belirlenir." hükümleri karara bağlanmıştır.

Katılım payının hukuktaki yeri gereği bu payın yasa ile ödenmesinin zorunlu olduğu, ödeme yapılmaması durumunda sağlık hizmetlerinde faydalanılamayacağı ve bu payın belirlenmesi ile ilgili olarak Sosyal Güvenlik Kurulu'nun bu konuda geniş yetkiye sahip olduğu anlaşılmaktadır.

Katılım payı uygulaması ile ilgili anayasa mahkemesinin iki kararı mevcuttur.

\subsection{Tarih ve 2006/111 Esas ve 2006/112 Karar sayılı Anayasa Mahkemesinin İlk Kararı: Katılım Payı Vergi Benzeri Bir Yükümlülük Değildir.}

Anayasa mahkemesi birinci kararında 68. maddede düzenlenen bu söz konusu payların, Anayasa'nın 73. maddesinde ifade edilen vergi, resim, harç ve benzeri mali yükümlülüklerden olduğu, Anayasa'nın Bakanlar Kurulunca (Cumhurbaşkanlığınca) kullanılmasına izin verilen söz konusu yetkinin Sosyal Güvenlik kurumuna verildiği, dolayısıyla bu kuralın Anayasa'nın 73. maddelerine aykırı olduğu iddialarını reddetmiştir (Batırel, 2020:1017).

Anayasa Mahkemesinin karar gerekçesi ise; "ücret, aidat, kesenek, harç, katılma payı, fon payı, katkı payı gibi adları ne olursa olsun parasal yükümlülük ya da ödemelerin Anayasa'nın 73. maddesi kapsamında mali yükümlülük sayılabilmesi için ödemenin kamu gideri niteliğinde ve kamu hizmeti karşılığı olması, tek taraflı irade ile alınması, esi halinde hukuki yolla tahsili, devlet tüzel kişiliği, kamu tüzel kişiliği ya da kamu kurumu niteliğinde meslek kurukamu gücüne dayanması, zorunlu olması, ödenmemluşları tarafından tahsil edilmesi ve yasa ile konulması gerekir." şeklinde ifade edilmiştir. 
Ayrıca Yüce Mahkemede; "kuraldaki tutarın normalde kişilerin kendilerinin karşılaması gereken sağhlk giderlerinin Devletçe karşılanması nedeniyle kendilerinden istenilen katkı payı olduğ u ve bu yönüyle Anayasa'nın 73. maddesindeki vergi, resim ve harç benzeri mali yükümlülük niteliğinde olmadığı anlaşılmaktadır." ifadesine yer verilmiştir.

Anayasa Mahkemesi ayrıca katılım payını Türkiye'nin de taraf olduğu Anayasa $\neg n ı n$ 90.maddesine göre temel hak ve özgürlüklerle ilgili düzenlemelerde yasalara üstün nitelikte olan uluslararası sözleşmelere uygun görmüş ve gerekçesi; "Diğer taraftan, sağlık yardımları için sigortalıdan katkı payı alınabileceği uluslararası sözleşmelerde de öngörülmüştür. "Sosyal Güvenliğin Asgari Normlarına İlişkin" Uluslararası Çalışma Örgütü'nün 102 sayılı Sözleşmesi'nin 10. maddesinde, sağlık yardımından faydalananlar veya bunların aile reislerinin, hastalık halinde yapılacak să̆lık yardımı masraflarına iştirak ettirilebileceğgi belirtilmekte, bunun ilgiliye ă̆ır bir yük getirme ᄀyecek şekilde tespit edilmesi öngörülmektedir. Avrupa Konseyi çerçevesinde oluşturulan Avrupa Sosyal Güvenlik Sözleşmesine göre de, korunan kimselerin doğrudan katkıda bulunmaları olanaklıdır. Türkiye, belirtilen iki sözleşmeye de katılarak onaylamıştır." şeklinde ifade edilmiştir.

Uluslararası sözleşmelerde yer alan hizmetlerden fayda sağlayanlardan bir katkı payı alınabilir düzenlemesi de tahsil edilecek katkının yasal olarak Anayasanın 73. maddesinde yer alan vergi benzeri yükümlülüklere uygun olmasını öngörmektedir. Söz konusu durum da bilindiği üzere genel sağlık sigortası primi ödeyerek sağlanmaktadır. Dolayısıyla Anayasa Mahkemesi'nin red gerekçelerini verdiği; “Bu ödeme vergi benzeri yükümlülük saᄀyılamaz, uluslararası sözleşmeler pay alınmasına izin vermektedir" içtihadı anayasaya uygun bir yorum olarak kabul edilememektedir (Batırel, 2020:1018).

\subsection{Tarih ve 2012/33 Esas ve 2012/174 Karar sayılı Anayasa Mahkemesinin Son Kararı: Katılım Payı Konusunda SGK'na Verilen Düzenleme Yetkisi Anayasaldır}

Anayasa Mahkemesi, vermiş olduğu ilk kararında, söz konusu payın vergi ve benzeri yükümlülük kapsamı dışında olduğu, katılma payı tahsil edilmesinin Türkiye'nin taraf olduğu uluslararası sözleşmeler dikkate alındığında da tahsil edilmesinin mümkün olduğuna yönelik hüküm vermiştir. Söz konusu hüküm sonrası 5510 sayılı Kanunda yapılan değişiklik ile "bu paya yeni bir özellik kazandırıldıา̆̆l, söz konusu maddenin içeriği bütünüyle değiştirildiği ve Kuruma tanınan yetkiyi asli düzenleme yetkisi niteliğine ulaştırdığı" iddia edilmiş Yüce Mahkemede bir dava ikame edilmiştir (Batırel, 2020:1020).

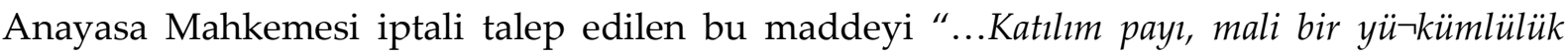
olmasına rağmen prim gibi, sağllk hizmetini kullanan ve kullanmayandan alınan bir tutar değildir. Kişilerin sigortalılık bilincinin arttırılması ve ödemenin başحtan yapıldı̆̆ı durumlarda hizmetin amaca uygun olarak kullanılmasını sağlamak amaาcıla getirilmiş bir uygulamadır. İlgililerin să̆lık hizmetinden faydalanmaların engel-lemeyecek düzeyde tutulması koşuluyla katılım payı alınması, sağlık harcamalarının devlet üzerindeki mali yükünü azaltmak amacıyla tedavi masraflarının bir kısmının hasta tarafindan karşılanmasımı să̆lamak, hastayı, să̆lık koruma masrafları konusun $\neg$ da bilinçli hâle getirmek ve hastayı gereksiz sağlık hizmeti kullanımından vazgeçirmek şeklinde tamamlayıcı amaçlara da hizmet etmektedir. Dava konusu kuralla getirilen katılım payı miktar ve oranlar sağlık hizmetinden yararlanan kişilerin ödeme durum ᄀları göz önünde bulundurularak koruyucu mekanizmalarla desteklendiğinden kişilerin să̆lığa erişim hakkını engelleyici nitelikte değildir. 
Dava konusu kuralda, katılım payı miktar ve oranlarıla ilgili kullamılan kıstaslarda belirsizlik bulunmamaktadır. Nitekim kanun koyucu, müracaat edilen sağlık hizmeti sunucusunun hangi basamakta yer aldiğl, sağlık hizmeti sunucusunun resmi ve özel sağllk hizmeti sunucusu niteliğinde olup olmadığı, bir önceki basamaktan sevkli olarak başvurulup başvurulmadığg gibi hususları göz önünde bulundurarak, katılım payını on katına kadar artırmaya ve sağlık hizmeti sunucuları için farklı oranlarda belirlemeye idareyi yetkili kılmıştır. Dolayısıyla kanun koyucu, dava konusu kuralda temel kıstaslar belirlemiş, bilimsel gelişmeler ve değişen koşul ve durumlara göre, hizmetin gerekleri doğrultusunda, idareye katılım payını kaldırma veya farklı oranlarda belirleme imkânı tanımıştır. Bu nedenle dava konusu kuralın belirsiz olduğu söylenemez." gerekçesi neticesinde iptal talebinin reddine oybirliği ile karar vermiştir.

Fakat Anayasa Mahkemesinin ifade edilen kararında da birinci kararında vermiş olduğu gibi yine uluslararası sözleşmeler kaynak gösterilmekte, söz konusu payın tahsil edilmesinin sağlık harcamalarının devlet üzerinde oluşturduğu yükü hafifletmek, hastayı gereksiz sağlık hizmetlerinden caydırma amaçları içerdiğinden sağlığa erişim hakkına engel olmadığı savunulmuştur.

Fakat idareye verilen geniş yetkinin çıkarılan Sağlık Uygulama Tebliğleri ile kullanılmasında ve çok sık değiştirilmesinde davaya konu olan kuralın belirsizlik kazandığı ve yasallık ilkesine aykırılık teşkil ettiği söylenebilir (Batırel, 2020:1020).

\section{SONUÇ}

Katılma paylarından benzeri mali yükümlülük olarak kabul edilen ve belediyelerin gelir kaynaklarından bir kalemi oluşturan harcamalara katılma payları 2464 sayılı Belediye Gelirleri Kanunu'nda yer verilen belediye gelirleri arasında yer almaktadır. Harcamalara katılma payları şeklinde ifade edilen yol harcamalarına, kanalizasyon harcamalarına ve su tesisleri harcamalarına katılma payları kamu gücüne bağlı olarak kamu giderlerinin karşılanması, kamusal tesislerin inşası, onarımı, vb. faaliyetleri dolayısıyla ortaya çıkan giderlere doğrudan katkı olarak tahsil edilmektedir. Söz konusu katılım paylarının matrahı olarak gayrimenkullerin vergi değerleri dikkate alınmaktadır.

Cebren alınması, geri ödemenin mümkün olmaması gibi özellikleri dolayısıyla vergiye benzeyen harcamalara katılma payı, kamu kurumları tarafından sağlanan belirli hizmetlerden fayda elde etme ya da belirli bir işin veya hizmetin karşılanması amacıyla yetkili makamlarca verilen izin neticesinde tahsil edilmesi bakımından harca, vergi benzeri mali yükümlülüğe ve resme benzetilebilmektedir.

Vergi dışında kalan resim, harç ve benzeri mali yükümlülüklere mali güce göre ödeme ilkesinin uygulanması söz konusu değildir. Fakat bu ilkeye kaynak eden sosyal hukuk devleti, adalet ilkeleri, kanun önünde eşitlik, demokratik toplum düzeninin ihtiyaç duyduğu ilkeler ve ölçülülük ilkesine uygunluk gibi ilkeler dikkate alınarak mali güce göre ödeme ilkesinin denetimde kullanılabileceğine dikkat çekilmektedir. Ama Anayasa Mahkemesi vergi benzeri yükümler hakkındaki davalarda eşitlik ilkesi, hukuk devleti ilkesi ve demokratik toplum düzeninin gereklerine yönelik incelemelerde bulunmuştur.

Maliye literatüründe gelir, servet ve harcamalar mali gücün göstergeleri olarak kabul edilmiştir. Bu göstergelerden servet, harcamalara katılma paylarında esas olarak alınmıştır. Belirli bir dönemde mal varlığına dahil tüm ekonomik değerler toplamı servet olarak kabul 
edilirken, harcamalara katılma paylarına ise servet unsurlarından sadece biri olan gayrimenkuller(sadece belediye hizmeti ile ilişkili olanlar) girmektedir. Dolayısıyla tüm serveti kapsamadığı için mali gücü gerçekte tespit edemediğinden vergi adaletine olumsuz etki edebileceği söylenebilir. Bunun yanında rayiç bedel ile emlak vergisi değeri arasındaki önemli farklılıklar da adalet ilkesini zedelediği söylenebilir. Ayrıca belediye tarafından sunulan hizmetlerin zamanı ve maliyetleri hakkında mükelleflerin bilgi sahibi olmaması da verginin uygunluk ve belirlilik ilkeleri ile bağdaşmamaktadır.

Resim benzeri mali yükümlülük olarak sınıflandırılan harcamalara katılma payının, gayrimenkulün vergi değeri dışında mali güç ilkesi dikkate alınması ve söz konusu ilkenin vergi sınıflandırmasında yer alan vergilerden birine (gelir, servet, harcama vergileri) dayandırılarak alınması Anayasa'nın 73. maddesinin özüne uygun bir yaklaşım olmakla birlikte katılma payının mükellef sayısının çokluğu ve ödeme gücü dolayısıyla toplumun bir çok kesimini bünyesinde bulundurması gerçeği dikkate alındığında milyonlarca kişinin ilişkisinin bulunduğu bir yükümlülüğün ödeme ilkesinin dikkate alınmayarak tahsil edilmesinin Anayasa'nın sosyal hukuk devleti ilkesi, eşitlik ilkesi, 73. maddesinde yer verilen ödeme gücü ilkesinin yanı sıra devletin ödevlerini düzenleyen 5. maddesi hükmüyle çelişeceği söylenebilir.

Kanalizasyon harcamalarına katılma payının tahsil edilebilmesi için, gayrimenkulün, tesisin yapılması ya da imar edilen kanalizasyondan fayda sağlıyor veya ileriki zamanlarda fayda elde edilecek olması gereklilik arz etmektedir. Su tesis harcamalarına katılma payı tahsil edilebilmesi için içme suyu şebekelerinin yeni tesis edilmesi ya da önceden tesis edilen şebekelerin genişletilmesi veya imar edilmesi gerekmektedir. Gayrimenkullerin iki veya daha fazla yol kenarında bulunması durumunda, söz konusu yollardan hangisinin şebekesine bağlantısı yapılmışsa, payın hesaplanmasında suya bağlanmış olduğu yol üzerindeki mesafeleri dikkate alınmaktadır. Dolayısıyla burada harcamalara katılma payı ile fayda elde etme düzeyi arasında kurulan ilişki, adalet ilkesi açısından önem arz etmektedir.

Vergi ödevinde kişinin, tanımı yapılmış olan bir hizmetten doğrudan fayda elde etmesinin bir karşılı olarak bir nakdi bedel ödemesi yerine, kamu hizmetleri dolayısıyla ortaya çıkan giderlerin tamamına karşı anonim bir katılma payını yüklenmesi söz konusudur. Altyapı tesislerinden doğrudan doğruya fayda elde edilmesinin bir karşılığı olarak tahsilatı yapılan nakdi değerin ifade edilen niteliği taşımaması dolayısıyla vergi ve benzeri mali yükümlülük olarak kabul görememektedir. Karayolları ve köprülerden alınan geçiş ücretleri, su elektrik, havagazı, demiryolları, havayolları gibi iktisadi kıstaslar neticesinde alınan ve hizmetin konusu, tesislerin bakım ve idamesini ve yeni yatırımlar yapılması amacı doğrultusunda belirlenmiş olan bir fiyat olması ve belirtilmiş olan nitelikler bakımından muayyen kamu hizmetleri karşılığı bireylerden alınan resim, harç ve benzeri mali yükümlülük olarak kabul görmesi söz konusu değildir. Bu nedenle, bunların "Gelir Ortaklığı Senedi" vasıtasıyla özel kişilere bırakılmasında Anayasa'nın 73. maddesine aykırı olmadığı söylenebilir.

Yasalar ile muhafaza edilen ve yaşama hakkını güvence altında tutan bir kamu hizmeti sayılan Să̆lık Hizmeti'nin sunumunda tahsil edilen katılım payının Anayasa'nın 73. maddesinde düzenlenen vergi ödevi kapsamında olan bir yükümlülük olduğu ve yasallık ilkesine aykırı olarak SGK'na geniş yetki verilmesi ile ilgili olarak Anayasa Mahkemesine açılan iki dava neticesinde Anayasa Mahkemesi, katılım payının Anayasaya aykırı olmadığı 
yönünde karar vermiştir. Türkiye'de yasallık ilkesi esaslarına uygun olmayacak şekilde düzenlenen Cumhurbaşkanlığına yetki tanınmayan, sürekli olarak değişen Sağlık Uygulama Tebliğleri dolayısıyla belirsizlik teşkil ettiği açık olan söz konusu katılım payının Mahkeme içtihatlarına rağmen Anayasaya uygunluğu tartışmalı olduğu söylenebilir.

\section{KAYNAKÇA}

15.12.2006 tarih ve 2006/11 esas 2006/112 karar sayılı Anayasa Mahkemesi kararı, 30.12.2006 tarih ve 26932 sayıl1 5. Mükerrer Resmi Gazete.

2464 sayılı Belediye Gelirleri Kanunu, 29.5.1981 sayılı Resmi Gazete, Sayı: 17354.

8.11.2012 Tarih ve 2012/33 Esas ve 2012/174 Karar sayılı Anayasa Mahkemesi Kararı, 21.09.2013 Tarih ve 28772 sayılı Resmi Gazete

Acar, F. ve Aydın F. (2015). Tüm Yönleri ile Belediye Gelirleri-Vergiler, Harçlar, Ücretler, Katılım Payları. Ankara: Türkiye Belediyeler Birliği (TBB).

Akdoğan, A. (2009). Kamu Maliyesi. Ankara: Gazi Kitabevi.

Altay, A. (2015). Kamu Maliyesi. Ankara: Seçkin Yayınları.

Anayasa Mahkemesi 28.03.2002, E. 2001/5, K. 2002/42 sayılı kararı, Resmi Gazete, 05.09.2002, S. 24867.

Anayasa Mahkemesinin 20.03.2008 tarih ve E.2004/94, K.2008/83 sayılı kararında (R.G.T. 01.07.2008, Sa.26923)

Antalya, O.G. (2019). Borçlar Hukuku Genel Hükümler, 5(1-2). Ankara: Seçkin Yayınları.

Arıkboğa, Ü. (2016). “Türkiye'de Belediyelerin Gelir Yapısı: Sorunlar ve Çözüm Önerileri”, Mustafa Kemal Üniversitesi Sosyal Bilimler Enstitüsü Dergisi, 13(33), ss. 276-297.

Arıkboğa, Ü. (2019). “Çevre Politikasının Ekonomik Araçları ve Türkiye'de Belediye Uygulamaları", Marmara Üniversitesi İktisadi ve İdari Bilimler Dergisi, 41(1), ss. 23-50.

Arslan, M. (2014). “Kentsel Rantların Vergilendirilmesi”, Ankara Barosu Dergisi, 3(3), ss. 115134.

Batırel, Ö. F. (2020). “Türkiye'de Sağlık Hizmeti Sunumunda Katılım Payı Uygulamasının Anayasaya Uygunluğu", Marmara Üniversitesi Hukuk Fakültesi, Hukuk Araştırmaları Dergisi, ss. 1013-1020.

Budak, T. ve Benk S. (2011). "Kamu Alacağ1: Hukuki Bir Değerlendirme”, Business and Economics Research Journal, 2(2), ss. 67-76.

Eraslan, Y. ve Üstün Ü. S. (2018). “İdare ve Vergi Mahkemeleri Arasında Çıkan Görev Uyuşmazlıkları ve Çözümünde Esas Alınan Ölçütler", Selçuk Üniversitesi, Hukuk Fakültesi Dergisi, 26(2), ss. 149-179.

Erdoğan, İ. (2019). Borçlar Hukuku Genel Hükümler. Ankara: Gazi Kitabevi.

Gerçek, A. (2010). Kamu Alacaklarının Takip ve Tahsil Hukuku. Bursa: Ekin Yayınları.

Güneş, G. (2008).Verginin Yasallığı İlkesi. İstanbul: Levha Yayınları.

Herekman, A. (1989). Kamu Maliyesi (Genel Vergi Kuramı). Ankara: Sevinç Matbaası. 
İpek, S. ve Engin, R. (2016). “Belediye Gelirleri İçinde Harcamalara Katılma Paylarının Yeri ve Önemi: Çanakkale Belediyesi Örneği”, Yönetim Bilimleri Dergisi, 14(28), ss. 467-481.

Kayıhan, Ş. ve Ünlütepe, M. (2018). Borçlar Hukuku Genel Hükümler. Ankara: Seçkin Yayınları.

Kurtuluş, B. (2006). Türkiye'de Belediyelerin Mali Yapısı ve Harcamaların Finansmanı. Ankara: Devlet Planlama Teşkilatı Yayınları.

Muter, N. B., Çelebi, A. K. ve Sakınç, S. (2008). Kamu Maliyesi. Manisa: Emek Matbaası.

Öztürk, İ. (2016). Vergi Benzeri Mali Yükümlülükler. Ankara: Yetkin Yayınları.

Pehlivan, O. (2014). Kamu Maliyesi. Trabzon: Seçkin Yayıncılık.

Şen, H. ve Sağbaş İ. (2015). Vergi Teorisi ve Politikası. Ankara: Gazi Kitabevi.

Şentürk, S. Hayri (2018), 1961 ve 1982 Anayasalarında Vergilemede Ödeme Gücü İlkesine Yönelik Düzenlemeler, Vergi Raporu, Sayı:229, ss. 9-20.

T.C. Hazine ve Maliye Bakanlığı, Muhasebat Genel Müdürlüğü, https://muhasebat.hmb.gov.tr/mahalli-idareler-butce-istatistikleri, (Erişim: 30.11.2020).

T.C. Resmi Gazete, 26.06.1985, Sayı: 18793, https://www.resmigazete.gov.tr/arsiv/18793.pdf, (20.04.2020).

Toprak, D. (2017), “Türkiye'nin Çevre Politikasında Yerel Yönetimlerin Rolü: Yerel Yönetim Bütçesinin İncelenmesi", Maliye Araştırmaları Dergisi, Cilt:3, Sayı: 2, ss. 173-193.

Tortop, N., Aytaç, B., Yayman, H. ve Özer, M. A. (2014). Mahalli İdareler. Ankara: Nobel Yayınları.

Torun, F. (2017). Belediye Gelirleri (2464 sayılı Belediye Gelirleri Kanunu Çerçevesinde). Ankara: Adalet Yayınevi.

Turhan, S. (1982). Vergi Teorisi. İstanbul: İstanbul Üniversitesi Yayınları.

Uluatam, Ö. (2014). Kamu Maliyesi. Ankara: İmaj Yayınevi.

Ulusoy, A. ve Akdemir, T. (2017). Mahalli İdareler. Ankara: Seçkin Yayınları.

Yazıcl, D. A. (2018). Büyükşehir Belediyelerinin Alternatif Gelir Potansiyelleri: İstanbul Büyükşehir Belediyesi Üzerine Bir İnceleme. Yüksek Lisans Tezi. Ankara: Hacettepe Üniversitesi, Sosyal Bilimler Enstitüsü.

Yılmaz, G. ve Biyan Ö. (2016). “Vergi Hukukunda Bir Belirsizlik: “Benzeri Mali Yükümlülük" Kavramı ve Bu Kavram Açısından Bakanlar Kuruluna Verilen Yetkilerin Değerlendirilmesi", Marmara Üniversitesi, İktisadi ve İdari Bilimler Dergisi, 38(2), ss. 335-360.

Yiğit, U. (2018). “Harcamalara Katılma Paylarının Mali Güce Göre Ödeme İlkesi Kapsamında Analizi", Maliye Dergisi, 0(174), ss. 431-454. 